\title{
THE STATUS OF OPTIONAL DISCIPLINES IN THE SCHOOL BASED CURRICULUM OF UPPER-SECONDARY SCHOOL: A CASE OF ROMANIA
}

\author{
Valentin Cosmin Blândul, Adela Bradea \\ Valentin Cosmin Blândul, Adela Bradea
University of Oradea, Romania \\ E-mail: bvali73@yahoo.com, adelabradea@yahoo.com
}

\begin{abstract}
The school curriculum includes the learning experiences students are invited to go through in an organized and systemic way. The curriculum has two main parts, the core curriculum and the school based curriculum (SBC) respectively. The latter one concerns the learning experiences, which school provides in addition to the minimum experiences that all students should gain and it can be achieved through optional school disciplines. However, education research has shown that the way these optional disciplines are chosen often expresses the teachers' options rather than those of the students. The main aim of this study was to analyze the subjective perception of upper-secondary school students with regard to the status of optional disciplines within the SBC. The sample consisted of 121 students, who study in 4 uppersecondary schools from Oradea, Bihor County, Romania. The instrument used was a questionnaire, and the implementation period was October-December 2014. The results show that the reasons why students choose a certain optional discipline are related to their need for personal and professional development. The most important subjects students want to study are foreign languages and sports activities, and the favored forms of organization include extracurricular and applied activities.
\end{abstract}

Key words: extracurricular activities, optional disciplines, school-based curriculum.

\section{Introduction}

The term curriculum involves a complex system of decisional, managerial and monitoring processes which precede, accompany and follow the design, elaboration, implementation, evaluation, as well as the permanent and dynamic revision of the set of learning experiences offered to children at school (Creţu \& Iucu, 2012, 6). In the Romanian education system the operational curriculum consists of: the core curriculum (approximately $65-70 \%$ of the National Curriculum) and the school-based curriculum (approximately 30-35\% of the National Curriculum). The school-based curriculum (SBC) is the set of educational processes and learning experiences which each school offers directly to its students within its own curricular offer. At the level of curricula from Romania, the SBC represents the number of teaching hours allotted to schools to build their own curricular projects. That covers the balance between the teaching hours in the core curriculum and the minimum or maximum teaching hours per week for each school discipline as they are mentioned in the framework-curriculum for each year of study (Bradea, 2014).

In this context, the optional disciplines are considered actual subjects of study and/or transdisciplinary themes/modules, opportunities to provide the students with individual study itineraries, in accordance with their interests and abilities, concrete ways for the teachers to 
Valentin Cosmin BLÂNDUL, Adela BRADEA. The status of optional disciplines in the school based curriculum of upper-secondary school: A case of Romania

OF EDUCAT

IN THE $21^{\text {st }}$ CENTURY Volume 63, 2015

show their professional and psycho-pedagogical mastery in the topics they are interested in and, on the other hand, they are also opportunities for students to choose the field in which they want to develop skills and abilities and shape their own system of attitudes and values (Giurgea, 2007, 16). At the same time, they also form the framework offered by school to students to choose their own learning paths, and it also helps parents choose a school based on what it offers.

\section{Problem of Research}

The importance of capitalizing on the SBC in school comes from the need for a more participatory education system, which meets local requirements and integrates with the labor market. This aspect is strongly related to decentralization policies in education, which are different in each country. There are countries in Europe, such as Finland, Denmark, The Netherlands, Austria, the UK, Germany etc., where the SBC takes an important place in the national curriculum, and, moreover, it is developed in cooperation by education authorities, social partners, business partners, the local community, and the outcome is a result-focused curriculum (Cedefop, 2012, Davis, 2009, Law, \& Nieveen, 2010).

The Netherlands is the country with the most decentralized education system in Europe. However, Finland is the country where learning results are among the best in the world. The Finnish education system is mainly based on trust in teachers and their expertise in developing curriculum. In Sweden, after 1990, the responsibility of developing the curriculum was gradually transferred from central authorities to schools. The same process has taken place in Ireland. Here, the focus has been on the professional training of teachers and on their teamwork so that they can develop educational strategies. The ultimate goal is to achieve high qualities in curriculum implementation.

In the Southeast European countries, in the former communist ones in particular, the decentralization process is greatly delayed. Nevertheless, integration with the European education has imposed curricular reforms, which have been carried out with more or less difficulties, depending on the national policies and strategies.

Bolstad (2004, pp. 7-8), claims that SBC has an important role even in those countries where there is still a significant centralization of the education system. She mentions four possible roles SBC could take in the new operational environments: better meet the needs and interests of students and of the school community; embed school learning in local contexts, knowledge, and resources, to meet both local and national aspirations; be responsive to new ideas and technologies in education; and take advantage of opportunities created by new curriculum and assessment structures.

In the Romanian education system, there is a legal framework for the implementation of the SBC, but this component of the curriculum does not focus as much as it should on the needs and expectations of the learners, on the development of an individual itinerary. The attention given to the opportunities offered by the SBC decreases gradually from primary to secondary schools, and then on to upper-secondary schools, where the majority of the SBC classes are used to deepen knowledge acquired within the core curriculum. In this way, the specific role and the target group of the optional disciplines are lost.

The lack of trust in optional disciplines is caused by:

- The difficulty to work in groups, which would be required in order to apply those modern methods and techniques that bring the expected results;

- The high amount of energy and time needed to prepare and hold these classes;

- The lack of financial incentives;

- The last years' financial constraints.

Teachers' initial training and their professional development can help them to a great extent to develop new skills, abilities and techniques they could use in their work, mainly in designing and teaching an integrated curriculum within a team. The major changes should, 
however, concern the decisions that can be taken at a school level. This is particularly true in Romania, as the emphasis here is placed on teaching those aspects of the curriculum that have been tested at a national level. The situations in which the students' knowledge is assessed could be extended to informal learning contexts, for example, in the case of social and civic competences. The students' active participation in school activities and in those of the community is an integrated component of social and civic competences in most European countries, one third of them take this participation into account in various forms of summative assessment (EACEA/ Eurydice, 2012b, p. 30).

\section{Research Focus}

According to the methodology in force in Romania, in the upper-secondary school curriculum the optional disciplines are grouped in optional packages that match with certain fields of training, which are in line with the objectives and the managerial plan of the school. Each package includes the disciplines suggested for the following years. In this way a consistent education itinerary is provided and when the student opts for a package that meets their aspirations, they will make an informed choice. The offer should cover at least twice the number of teaching hours they can opt for. Once the option for a certain discipline has been stated, this becomes compulsory for the period it has been planned to be taught: a semester, a year, two years or more years.

Practice has shown that most optional disciplines are taught for a period of one year. This is also due to the fact that in many cases the optional disciplines are used to complete teaching loads. This means that they are not chosen by the students and, obviously, cannot be taught for longer periods. Furthermore, the students' feedback, which should be the decisive barometer in choosing optional disciplines or a package of optional disciplines, is missing almost altogether.

Optional disciplines are taught in schools either for groups or for whole classes. At the beginning, in 1998, when these disciplines were included in the framework-curriculum, they were always taught for groups and had their place in the timetable, which offered the students the possibility to assess their quality and to exchange opinions. Unfortunately, after 2000, this controllable, comfortable and beneficial way - both for teachers and students - of holding the classes has almost entirely vanished, although the methodology states clearly that optional disciplines can be taught for either classes or groups of 10-15 students, based on the facilities of the schools. In the current context of Romania, where the number of students is constantly declining, there is enough room in schools to return to the initial practice. According to the law in force, groups can be set up by choosing from more classes students who have opted for the same discipline, and one class can be divided into two groups with different optional disciplines, which are taught by two different teachers. It is regrettable that this clear stipulation is not applied in the schools of the country, mainly due to financial constraints. It is statistically very unlikely that all the students of a class are interested in only two optional disciplines. If that is the case, either the offer of the school is extremely limited, or the students' options are superficial.

The aim of this study was to analyze the opinion of upper-secondary school students on the status of optional disciplines made available to them within the SBC. 
Valentin Cosmin BLÂNDUL, Adela BRADEA. The status of optional disciplines in the school based curriculum of upper-secondary school: A case of Romania

OF EDUCATION

IN THE $21^{\text {st }}$ CENTURY

Volume 63, 2015

Methodology of Research

\section{General Background of Research}

As it can be seen from the theoretical background of the study, the optional disciplines included in SBC have a key role in developing the students' personal competences and professional skills. These disciplines are elaborated by the school's teachers, based on the particular conditions of teaching. In addition, by choosing their optional disciplines, students have the opportunity to plan their own professional study path, in line with their individual characteristics (Blândul, 2014).

The objectives of the study were: (1) understanding the motivations behind students' choice of a certain optional discipline; (2) finding the most important topics these students would like to study about within the optional disciplines and (3) analyzing the students' opinions on the main teaching strategies used by teachers in teaching/assessing students' results in optional disciplines. In addition, it was assumed that the most objective indicator that can show the status of optional disciplines within the SBC is given by the degree to which students are consulted and, related to that, the freedom they have to choose those disciplines which they want to study. Therefore, the specific hypothesis of the study was the following: there are significant statistical differences between the degree to which students are consulted about the inclusion of an optional discipline in the SBC and the specialization of the school they study at.

\section{The sample of Research}

The sample of the research consisted of $121(\mathrm{~N}=121)$ students, with ages between 15 and 16 years, who study at four schools in Oradea, Bihor county, Romania: „Emanuel Gojdu” National College, „Mihai Eminescu” National College, „Onisifor Ghibu” Upper-secondary School and „Lucian Blaga” Upper-secondary School. It should be mentioned that in Oradea there are only four upper-secondary schools where students can pursue theoretical studies in sciences and humanities, those included in the research, and these are the only schools where students can choose optional disciplines. This explains the number of participants included in the research. $60.8 \%$ of the students were girls and $39.2 \%$ were boys, $81(66.94 \%)$ pursue studies in sciences and $40(34.06 \%)$ in humanities, $57.3 \%$ are in the $10^{\text {th }}$ and $46.7 \%$ in the $11^{\text {th }}$ grade respectively. The simple random sampling procedure was used for choosing the participants of the sample - out of the total number of 1,253 students in the four schools each $10^{\text {th }}$ name was picked. From a statistical point of view, the number of participants was an optimal one for the sample to be representative for the number of students in the four schools.

\section{Instruments and Procedure}

The instrument used in the research was a questionnaire that consisted of 28 questions, both open-ended and close-ended, 10 items and 18 items respectively. The questions were grouped in the following categories: students' motivation for choosing a certain optional discipline, the topics dealt with within these optional disciplines, teaching strategies used in teaching these disciplines and in assessing the students' results, as well as the students' participation rate in choosing a certain discipline for the SBC. The questionnaire was prepared by educationalists from the Center for Interdisciplinary Research of Oradea University (see www.uoradea.ro) and each student included in the sample filled in its printed version. The study was carried out from October to December 2014. 
Valentin Cosmin BLÂNDUL, Adela BRADEA. The status of optional disciplines in the school based curriculum of upper-secondary school: A case of Romania

\section{Data Analyses}

The SPPS software was used for the statistical processing of the data obtained. The frequency of students' answers was calculated, both for the entire sample and also broken down by the studies pursued, sciences and humanities respectively. For the validation of the specific hypothesis of the study, the $\chi^{2}$ (chi square) coefficient was calculated for the differences between the students' participation rate in decisions concerning the optional disciplines included in the SBC and the studies pursued by them.

\section{Results of Research}

The results show that only $34.71 \%$ of the respondents say that they were consulted about the inclusion of an optional discipline in the SBC, while only $31.4 \%$ admitted that they had broad freedom concerning the optional disciplines they wanted to study. The other results are shown in the tables below.

Table 1. Motivation behind the choice of optional disciplines.

\begin{tabular}{|c|c|c|c|c|c|c|}
\hline \multirow{3}{*}{ Indicator } & \multirow{2}{*}{\multicolumn{2}{|c|}{$\begin{array}{l}\text { Frequency of } \\
\text { answers }\end{array}$}} & \multicolumn{4}{|c|}{ Answers according to the studies pursued } \\
\hline & & & \multicolumn{2}{|c|}{ Sciences } & \multicolumn{2}{|c|}{ Humanities } \\
\hline & $\mathrm{N}$ & $\%$ & $\mathrm{~N}$ & $\%$ & $\mathrm{~N}$ & $\%$ \\
\hline Personal development & 47 & 38.86 & 27 & 33.08 & 19 & 49.33 \\
\hline $\begin{array}{l}\text { Deepening knowledge acquired during } \\
\text { compulsory school subjects }\end{array}$ & 42 & 34.59 & 38 & 47.05 & 5 & 12 \\
\hline Professional development & 16 & 13.76 & 8 & 9.53 & 7 & 21.33 \\
\hline Relaxation & 11 & 9 & 5 & 6.67 & 6 & 13.34 \\
\hline Not applicable & 5 & 3.79 & 3 & 3.67 & 3 & 4 \\
\hline TOTAL & 121 & 100 & 81 & 100 & 40 & 100 \\
\hline
\end{tabular}

The first table shows the motivation behind the students' willingness to study a certain optional discipline. Looking at the entire sample, it can be seen that the most frequent motives mentioned by the students are connected with the need for personal and professional development, as well as the deepening of knowledge acquired during the study of compulsory subjects (Table 1). The priorities change when the results are analyzed based on the studies pursued. Thus, the students who study sciences prefer those optional disciplines that help them deepen theoretical compulsory knowledge, while those who study humanities place the need for personal and professional development before the other motives. Furthermore, 13.34\% of the students belonging to the latter group regard optional disciplines as a way of relaxation and entertainment. These results confirm the idea that the optional disciplines take a very important place within the school curriculum, as they complete the compulsory subjects and significantly contribute to the students' better training. 
Valentin Cosmin BLÂNDUL, Adela BRADEA. The status of optional disciplines in the school based curriculum of upper-secondary school: A case of Romania

PROBLEMS

OF EDUCATION

IN THE $21^{\text {st }}$ CENTURY

Volume 63,2015

Table 2. The topics optional disciplines should deal with.

\begin{tabular}{lllllll}
\hline \multirow{2}{*}{ Indicator } & \multicolumn{5}{l}{$\begin{array}{l}\text { Students' answers according to the studies } \\
\text { pursued }\end{array}$} \\
\cline { 2 - 7 } & \multicolumn{2}{l}{ Frequency of answers } & & \multicolumn{2}{l}{ Sciences } & \multicolumn{2}{l}{ Humanities } \\
\cline { 2 - 7 } & $\mathrm{N}$ & $\%$ & $\mathrm{~N}$ & $\%$ & $\mathrm{~N}$ & $\%$ \\
\hline Artistic activities & 32 & 26.47 & 14 & 17.77 & 19 & 45.21 \\
\hline Science and environment & 28 & 22.93 & 27 & 33.04 & 1 & 1.06 \\
\hline Modern foreign languages & 19 & 16.18 & 12 & 14.56 & 7 & 19.68 \\
\hline Sporting activities & 17 & 14.53 & 10 & 12.09 & 7 & 19.68 \\
\hline $\begin{array}{l}\text { Education in entrepreneurship and } \\
\text { economics }\end{array}$ & 13 & 10.96 & 11 & 13.86 & 2 & 4.78 \\
\hline Culture and society & 12 & 8.93 & 7 & 8.68 & 4 & 9.59 \\
\hline Total & 121 & 100 & 81 & 100 & 40 & 100 \\
\hline
\end{tabular}

The topics the students of the sample would like to see included in the optional disciplines cover a wide range, from artistic activities to science and environment, modern foreign languages and so on (Table 2). The same preferences, but in a different order, can be seen when the answers are analyzed based on the studies pursued. Thus, most students who study sciences are interested in topics related to science and environment, while their peers from humanities want to develop themselves in the fields of arts and of foreign languages. The students in this second group have a particular interest in sporting activities, which correlates with their need for relaxation and entertainment as shown in Table 1. Moreover, the connection between the students' motivation behind their choice of a certain optional discipline and the topic they expect it to deal with becomes obvious as long as the students who study sciences prefer to deepen knowledge from the fields of science and environment (their specialization), while their peers who study humanities prefer personal development through arts (Tables 1 and 2).

Table 3. Activities organized within the optional disciplines.

\begin{tabular}{lllllll}
\hline \multirow{2}{*}{$\begin{array}{l}\text { Indicator } \\
\text { Frequency of an- } \\
\text { swers }\end{array}$} & \multicolumn{4}{l}{$\begin{array}{l}\text { Students' answers according to the studies } \\
\text { pursued }\end{array}$} \\
\cline { 2 - 7 } & $\mathrm{N}$ & $\%$ & $\mathrm{~N}$ & $\%$ & $\mathrm{~N}$ & $\%$ \\
\hline $\begin{array}{l}\text { Activities outside the school / extracur- } \\
\text { ricular activities }\end{array}$ & 25 & 20.4 & 18 & 20.37 & 9 & 20.46 \\
\hline Practical-applied activities & 22 & 18.57 & 15 & 18.33 & 8 & 18.71 \\
\hline Group activities in the classroom & 21 & 17.75 & 14 & 17.17 & 7 & 17.54 \\
\hline Laboratory activities & 16 & 13.26 & 15 & 18.33 & 2 & 4.1 \\
\hline Examples of good practice & 12 & 9.28 & 6 & 7.52 & 4 & 13.65 \\
\hline Debates & 11 & 8.97 & 7 & 9.71 & 3 & 7.6 \\
\hline Projects & 11 & 8.97 & 3 & 5.82 & 6 & 15.61 \\
\hline Case studies & 2 & 1.42 & 1 & 0.94 & 1 & 2.33 \\
\hline $\begin{array}{l}\text { The same as during classes in the } \\
\text { compulsory subjects }\end{array}$ & 1 & 1.38 & 2 & 1.81 & 0 & 0 \\
\hline TOTAL & 121 & 100 & 81 & 100 & 40 & 100 \\
\hline
\end{tabular}


Table 4. Teaching strategies used for assessing students' results in the optional disciplines.

\begin{tabular}{|c|c|c|c|c|c|c|}
\hline \multirow{3}{*}{ Indicator } & \multirow{2}{*}{\multicolumn{2}{|c|}{$\begin{array}{l}\text { Frequency of an- } \\
\text { swers }\end{array}$}} & \multicolumn{4}{|c|}{$\begin{array}{l}\text { Students' answers according to the studies } \\
\text { pursued }\end{array}$} \\
\hline & & & \multicolumn{2}{|c|}{ Sciences } & \multicolumn{2}{|c|}{ Humanities } \\
\hline & $\mathrm{N}$ & $\%$ & $\mathrm{~N}$ & $\%$ & $\mathrm{~N}$ & $\%$ \\
\hline Projects & 36 & 29.9 & 27 & 33.02 & 9 & 23.3 \\
\hline Practical tests & 31 & 26.16 & 25 & 31.19 & 6 & 15.33 \\
\hline Portfolio & 16 & 13.08 & 13 & 14.22 & 4 & 10.67 \\
\hline Oral tests & 13 & 10.59 & 6 & 7.75 & 7 & 16.5 \\
\hline Written tests & 13 & 10.59 & 3 & 3.66 & 11 & 25.47 \\
\hline $\begin{array}{l}\text { Self-assessment/peer assess- } \\
\text { ment }\end{array}$ & 8 & 6.85 & 5 & 6.88 & 2 & 6.79 \\
\hline Case study & 4 & 2.83 & 2 & 3.28 & 1 & 1.94 \\
\hline TOTAL & 121 & 100 & 81 & 100 & 40 & 100 \\
\hline
\end{tabular}

According to most students' opinions, the activities organized within the optional disciplines include extracurricular activities, practical-applied ones and activities that are based on cooperative learning (Table 3). A similar order can be seen in the case of answers based on the studies pursued, noting that in the case of the students who study sciences a particular place is taken by laboratory activities, and for those from humanities by research projects. Similar results were obtained when analyzing the students' opinions on the teaching strategies used to assess results in the optional disciplines (Table 4). The first places are taken by projects, practical tests and portfolio, and the results are the same in the case of answers based on the studies pursued by the students. Nevertheless, written tests stand out in the case of students who study humanities - more than $25 \%$ of them mentioned these tests. It can be seen that, as it could be expected, the teaching strategies used in teaching optional disciplines and in assessing the results obtained are adjusted to the students' training needs and to the particularities of the studies pursued, which means that emphasis is placed on practical and laboratory activities in the case of the students who study sciences and on projects for those who study humanities. This can mean that the optional disciplines do not represent an alternative to the compulsory disciplines as far as the teaching strategies are concerned, the novelty being given only by the new teaching content included.

Table 5. Statistical differences between the students' participation rate in decisions concerning the optional disciplines included in the SBC and the studies pursued by them.

\begin{tabular}{lll}
\hline Indicator & $\begin{array}{l}\text { Students who pursue stud- } \\
\text { ies in sciences }\end{array}$ & $\begin{array}{l}\text { Students who pursue studies } \\
\text { in humanities }\end{array}$ \\
\hline $\begin{array}{lll}\text { Students' participation rate in decisions concerning } \\
\text { the optional disciplines included in the SBC }\end{array}$ & $\chi^{2}=11.72$ & $\chi^{2}=1.48$ \\
\cline { 2 - 3 } & $p<0.01$ & $p<0.05$ \\
\hline
\end{tabular}

The specific hypothesis of the study wanted to show the existence of significant statistical differences between the sciences or humanities studies pursued by the students included in the sample and the degree to which they are consulted and have the possibility to influence 
Valentin Cosmin BLÂNDUL, Adela BRADEA. The status of optional disciplines in the school based curriculum of upper-secondary school: A case of Romania

OF EDU

PROBLEMS

IN THE $21^{\text {st }}$ CENTURY Volume 63, 2015

decisions concerning the optional disciplines included in the SBC. The calculation of the frequency of answers shows, that a bit over $30 \%$ of the respondents state that they are involved in decisions on optional disciplines. The statistical interpretations show that there are statistical differences between the students' participation rate in decisions concerning the inclusion of optional disciplines in the SBC and the studies pursued at a significance threshold lower than 0.01 for those who pursue studies in sciences and lower than 0.05 for those who pursue studies in humanities (Table 5). The results show that the education policies promoted in those uppersecondary schools included in the study where sciences are taught are more favorable to the students' participation in decision making. This means that the students are encouraged to get involved in building the SBC and, in a broader sense, in their entire training provided by school.

\section{Discussion}

A first aspect that should be discussed is the way optional disciplines are charted within the SBC. In their studies carried out in New Zealand on the SBC, Bolstad (2004) and Baldwin (2007) emphasized the important role played by the SBC in the students' development, as it opens a much larger horizon of opportunities for their personal and professional growth. The authors also pointed out that more than $60 \%$ of the upper-secondary school students are consulted about the choice of an optional discipline, and the final decisions are made by students and teachers of the school together. In Romania, policy makers at government level and educationalists agree that students are overloaded both in respect of the subjects they have to study and the numbers of classes, and they suggest increasing the share of optional disciplines so that the framework-curricula can be relaxed. The results of our study show that the optional disciplines to be included in the SBC and taught to students are selected mainly based on the managerial policies of the institutions, the availability of qualified teaching staff in a certain field or on the facilities and organizational resources available. Paradoxically, although they should be the first to consult, only $34.71 \%$ of the students (most of them pursuing studies in sciences) claim that they have been consulted about decisions concerning optional disciplines, which means that when choosing an optional discipline the variables taken into account have nothing to do with the opinions of those who are directly affected by these decisions. The results of the present study show that when choosing a certain optional discipline the aspects that should be taken into account are the students' motivation to study it, the topics preferred by them, the most effective teaching strategies etc. (Mason, 2009). After all, the very role of optional disciplines is to help students deepen knowledge acquired during compulsory courses, as well as to foster their personal and professional development. On the other hand, a complete freedom given to students could result in choosing easy optional disciplines, often of short-lived popularity, but with low relevance to their overall training. It is of utmost importance that a platform is found where the curricular offer of school and the students' training needs meet so that school can implement optional disciplines in a way that is pleasant and useful to students.

A second aspect that deserves discussion refers to capturing the psycho-pedagogical portrait of upper-secondary school students based on both the studies pursued and the optional disciplines studied. In an article published by Klosterman, Sadler \& Brown (Klosterman, Sadler \& Brown, 2012) the three educationalists showed that following a certain study path would leave its mark both on the students' personal development and on the way they would make choices in life. Thus, one would expect that most students who pursue studies in sciences should be more pragmatic, precise in their phrasing, analytical, sensible when making choices, focused on achieving goals and so on, while the behavior of most students who pursue studies in humanities might be subject to interpretation. The results of this study confirm the above theory. Thus, most students who pursue studies in sciences choose optional studies in order 
to deepen knowledge acquired during compulsory courses. They prefer topics that are related to science and they also opt for practical-applied extracurricular activities. On the other hand, in the case of their peers who pursue studies in humanities the motivation behind choosing an optional discipline is personal development, the topics are mainly related to the world of art and they favor extracurricular activities and projects. This certifies the theory which says that one of the fundamental roles of optional disciplines is to complete knowledge acquired compulsorily (studies in sciences), as well as to offer an educational alternative for the students' personal and professional development (studies in humanities). These roles should not be generalized, of course, they are complementary and they contribute to the students' preparation for life.

\section{Conclusions}

In the scholar literature it has been shown that the important role of optional disciplines included in the SBC is given by the fact that they cover those teaching contents which cannot be included in the core curriculum, while meeting the needs and interests of students. Nevertheless, although the students' opinions should be taken into account when optional disciplines are chosen for the SBC, the primary factors that influence decisions are the managerial policies of the institutions, the qualifications of the teaching staff and the facilities and organizational resources available in schools.

The results of the present study show that the majority of the students who pursue studies in sciences opt for those optional disciplines that allow them to deepen knowledge acquired during core courses, they prefer topics related to science and the environment, want to have extracurricular and laboratory activities in these classes and favor practical tests for assessments. On the other hand, in the case of most students who pursue studies in humanities, optional disciplines are chosen to help personal development, they prefer topics related to art and classes based on extracurricular activities, as well as written tests and projects for assessments.

Based on those presented above, it can be concluded that students who pursue studies in sciences prefer those optional disciplines which can be used to complete theoretical knowledge related to their specialization, while their peers who pursue studies in humanities assign to these disciplines an "alternative education" status, with a role in their personal and professional development. In reality, the two roles of the SBC should mutually complete each other and contribute to the development of a well-rounded personality so that students' optimal integration in the communities they belong to is achieved.

\section{References}

Baldwin, R. (2007). A way forward with the new Social Sciences curriculum: Approaches to planning programmes for schools. Paper is based on a presentation made at the National Biannual Conference for Social Sciences Educators (pp. 1-8). Auckland.

Blândul, V. (2014). Fundaments of formal education. Bucharest, Pro Universitaria Publishing House.

Bolstad, R. (2004). School-based curriculum development: Principles, processes, and practices. A background paper on school-based curriculum development for the New Zealand Curriculum Project, Wellington, N.Z.: New Zealand Council for Educational Research. Retrieved 6/03/2015, from http://www.tki.org.nz/r/nzcurriculum/whats_happening_e.php

Bradea, A. (2014). Elements of general education. Oradea: Oradea University Press.

Crețu, C., Iucu, R. (Ed.) (2012). Multicriteria analysis of policies on curriculum. Bucharest: Didactic and Pedagogic Publishing House.

Curriculum Reform in Europe. The impact of learning outcomes, European Centre for the Development of Vocational Training (Cedefop). No 29, Luxembourg: Publications Office of the European Union, 2012. Retrieved 2/02/2015, from http://corevet.eu/assets/site/files/5529_en.pdf 
Valentin Cosmin BLÂNDUL, Adela BRADEA. The status of optional disciplines in the school based curriculum of upper-secondary school: A case of Romania

PROBLEMS

OF EDUCATION

IN THE $21^{\text {st }}$ CENTURY Volume 63, 2015

Davis, P. (2009). Development Education and the School Curriculum in the European Union. A report on the status and impact of development education in the formal education sector and school curriculum in member states of the European Union. For CONCORD Development Education Forum: Curriculum Working Group and DEEEP. Retrieved 5/02/2015, from file://C:/Users/Administrator/Downloads/6._DE_and_School_Curriculum_report2009Final.doc

European Commission/EACEA/Eurydice, 2012. Developing Key Competences at School in Europe: Challenges and Opportunities for Policy. Eurydice Report. Luxembourg: Publications Office of the European Union. Retrieved 2/02/2015, from http://eacea.ec.europa.eu/education/eurydice/ documents/thematic_reports/145RO.pd

Fernandes, P., Leite, C., Mouraz, A., Figueiredo, C. (2013). Curricular contextualization: Tracking the meanings of a concept. The Asia-Pacific Education Researcher, 22 (4), 417- 425.

Giurgea, D. (2007). Methodological guide for optional disciplines. Bucharest: D\&G Editur Press.

Guţu, V. (2013). Pedagogy. CEP-USM, Chişinău, Republic of Moldova.

Klosterman, M. L., Sadler, T. D., Brown, J. (2012). Science teachers' use of mass media to address socio-scientific and sustainability issue. Research in Science Education, 42 (1), 51-74.

Law, E. H. F., Nieveen, N. (Ed.) (2010). Schools as curriculum agencies: Asian and European perspectives on school-based curriculum development. Rotterdam: Sense Publishers.

Mason, J. (2009). Teaching as disciplined enquiry. Teachers and Teaching: Theory and Practice, 15 (2), 205-223.

Advised by Florin Frumos, ”Al. I. Cuza” University of Iaşi, Romania

Received: February 02, 2015

Accepted: February 24, 2015

Valentin Cosmin Blândul

PhD., Associate Professor, University of Oradea, 1 University Street, Oradea, 410087, Bihor, Romania.

E-mail: bvali73@yahoo.com

Website: https://www.uoradea.ro/

Adela Bradea

PhD., Lecturer, University of Oradea, 1 University Street, Oradea, 410087,

Bihor, Romania.

E-mail: adelabradea@yahoo.com

Website: https://www.uoradea.ro/ 